TITLE:

\title{
Fluorine-doped tin dioxide thin films prepared by chemical vapor deposition
}

$\operatorname{AUTHOR}(S)$ :

MARUYAMA, T; TABATA, $\mathrm{K}$

CITATION:

MARUYAMA, T ...[et al]. Fluorine-doped tin dioxide thin films prepared by chemical vapor deposition. JOURNAL OF APPLIED PHYSICS 1990, 68(8): 4282-4285

ISSUE DATE:

1990-10-15

URL:

http://hdl.handle.net/2433/43532

\section{RIGHT:}

Copyright 1990 American Institute of Physics. This article may be downloaded for personal use only. Any other use requires prior permission of the author and the American Institute of Physics. 


\title{
Fluorine-doped tin dioxide thin films prepared by chemical vapor deposition
}

\author{
Toshiro Maruyama and Kenii Tabata \\ Department of Chemical Engineering, Faculty of Engineering, Kyoto University, Yoshida-Honmachi, \\ Sakyo-ku, Kyoto 606, Japan
}

(Received 18 April 1990; accepted for publication 18 June 1990)

\begin{abstract}
Transparent conductive tin dioxide thin films were prepared by a low-temperature atmospheric-pressure chemical vapor deposition method in air. The raw material was tin(II) triffuoroacetate. At a reaction temperature above $250^{\circ} \mathrm{C}$, polycrystalline thin films were obtained with a high deposition rate. This chemical vapor deposition method effectively incorporates $F$ atoms into a crystalline structure and consequently maximizes the carrier concentration, yielding fuorine-doped $\mathrm{SnO}_{2}$ films of very low resistivity. For the 1260 -nmthick film deposited at $400^{\circ} \mathrm{C}$, the resistivity was $5.92 \times 10^{-4} \Omega \mathrm{cm}$, and the sheet resistance was $4.69 \Omega /[$. The deposition condition, structure, and characteristics of films were compared to the corresponding values in the chemical vapor depositions of $\mathrm{SnO}_{2}$ from tin(II) acetate.
\end{abstract}

\section{INTRODUCTION}

Tin dioxide $\left(\mathrm{SnO}_{2}\right)$ is an $n$-type semiconductor which has many applications. In particular, $\mathrm{SnO}_{2}$ thin films doped with antimony or fuorine are widely used in practice as transparent condictive films. The advaniages of $\mathrm{SnO}_{2}$ film are high chemical and mechanical stabilities ever at high temperatures. These advantages find some applications in modern optoelectronic devices, such as solar cells.

High-quality $\mathrm{SnO}_{2}$ film has been prepared by spray pyrolysis and chemical vapor deposition (CVD) methods. ${ }^{1.3}$ The CVD method yielded antimony-doped films ${ }^{1,2}$ with a resistivity of $8-10 \times 10^{-4} \Omega \mathrm{cm}$, and the fuorine-doped films ${ }^{3}$ with a resistivity of $4.5 \times 10^{-4} \Omega \mathrm{cm}$. The tin precursor, e.g., organotin ${ }^{1,2}$ and $\mathrm{SnCl}_{4}{ }^{3}$ and oxygen donor have been used with a dopant source, e.g., $\mathrm{SbCl}_{30}{ }^{1}\left(\mathrm{CH}_{3}\right)_{3} \mathrm{Sb},{ }^{2}$ and $\mathrm{HF}^{3}$ In the CVD of coped $\mathrm{SnO}_{2}$, therefore, the deposition processes have suffered from a lack of reproducibility because of the large number of parameters which have to be controlled.

In this paper, $\operatorname{tin}(\mathrm{II})$ bis-trifucoroacetate is proposed as a precursor for obtaining fluorine-doped $\mathrm{SnO}_{2}\left(\mathrm{SnO}_{2}: \mathrm{F}\right)$ films. The low-temperature CVD of this precursor material, which involves bonds with fuorine atoms, yields fuorinedoped film with no need of supplying a fuorine donor. The preparation condition, structure, and characteristics of $\mathrm{SnO}_{2}: \mathrm{F}$ film will be discussed by comparing those for $\mathrm{SnO}_{2}$ films which were prepared from tin diacetate. Since the CVD of Sn(IV) dioxide from a Sn(II) compound includes oxidation processes, the $\mathrm{SnO}_{2}: \mathrm{F}$ and $\mathrm{SnO}_{2}$ films were also prepared by the CVD where $\mathrm{O}_{2}$ gas was premixed with the source gas; and the effects of the $\mathrm{O}_{2}$ gas premixing on deposition rate, crystallinity, and electric conductivity of film were discussed.

\section{EXPERIMENT}

Tin(II) trifuoroacetate $\left[\mathrm{Sn}\left(\mathrm{CF}_{3} \mathrm{COO}\right)_{2}\right.$, Nihon $\mathrm{Ka}$ gaku Sangyo Co., Ltd.] was used as the source material for preparing $\mathrm{SnO}_{2}: \mathrm{F}$, and $\operatorname{tin}(\mathrm{II})$ acetate $\left[\mathrm{Sn}\left(\mathrm{CH}_{3} \mathrm{COO}\right)_{2}\right.$, Nihon Kagaku Sangyo Co., Ltd.] was used for preparing
$\mathrm{SnO}_{2} \cdot \mathrm{Sn}\left(\mathrm{CF}_{3} \mathrm{COO}\right)_{2}$ and $\mathrm{Sn}\left(\mathrm{CH}_{3} \mathrm{COO}\right)_{2}$ were heated at temperatures of $140-160$ and $120-160^{\circ} \mathrm{C}$, respectively. The generated gases were entrained by carrier gases, which were mainly nitrogen. For $\mathrm{O}_{2}$ premixing experiments in preparing $\mathrm{SnO}_{2}$ film, $\mathrm{N}_{2}$ gas for carrying $\mathrm{Sn}\left(\mathrm{CH}_{3} \mathrm{COO}\right)_{2}$ was replaced by $\mathrm{O}_{2}$ gas. Meanwhile, for $\mathrm{O}_{2}$ premixing in preparing $\mathrm{SnO}_{2}: \mathrm{F} \mathrm{film}, \mathrm{O}_{2}$ gas was injected into pipeline (near the inlet of the reactor) where $\mathrm{Sn}\left(\mathrm{CF}_{3} \mathrm{COO}\right)_{2}$ is carried with $\mathrm{N}_{2}$ gas, because $\mathrm{Sn}\left(\mathrm{CF}_{3} \mathrm{COO}\right)_{2}$ is reactive with $\mathrm{O}_{2}$ even at low temperature.

A $76 \times 26 \mathrm{~mm}$ borosilicate glass plate was used as the substrate, which was placed in the open-tube reactor keated by an external electric furnace. The reaction temperature ranged from 200 to $500^{\circ} \mathrm{C}$.

The composition of the film was measured by $x$-ray photoelectron spectroscopy. The crystallinity of the film was analyzed by the $\mathrm{x}$-ray diffraction method with $\mathrm{Cu} K \alpha$ radiation. The electric resistivity and the Hall coeficient of the film were measured by the van der Pauw method. The optical transmittance of the film was obtained by means of a multipurpose recording spectrophotometer. A blank glass substrate was inserted into the reference beam path of the spectrophotometer.

\section{RESULTS AND DISCUSSION}

For two kinds of source materials, the deposition conditions were comparable; transparent conductive $\mathrm{SnO}_{2}$ and $\mathrm{SnO}_{2}: \mathrm{F}$ films were obtained in air at reaction temperatures above 200 and $250^{\circ} \mathrm{C}$, respectively. The films were not obtained in an inert (nitrogen) atmosphere. Thus, $\mathrm{O}_{2}$ gas is inferred to make a role in oxidation of the decomposition product. The lower limit of the reaction temperature is much lower than that for organotin ${ }^{1,2}$ and $\mathrm{SnCl}_{4}{ }^{3}$

Figure 1 shows the Arrhenius plot of deposition rates of $\mathrm{SnO}_{2}$, which were obtained at a source temperature of $120^{\circ} \mathrm{C}$ and carrier gas flow rate of $1 \mathrm{l} / \mathrm{min}$. The deposition rates for two kinds of carrier gas agree fairly well. Thus, the $\mathrm{O}_{2}$ premixing does not affect the deposition rate. The values of the deposition rate are of the same order of magnitude as those reported previously using the standard CVD methods. The 


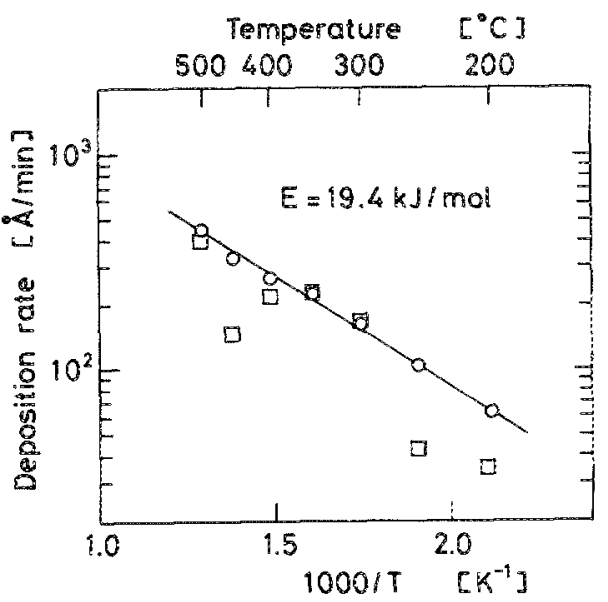

FIG. 1. Arrhenius plot of deposition rate of $\mathrm{SnO}_{2}$ film prepared from $\mathrm{Sn}\left(\mathrm{CH}_{3} \mathrm{COO}\right)_{2}$ without premixing $\mathrm{O}_{2}$ gas $(\mathrm{O})$ and with premixing $\mathrm{O}_{2}$ gas (a).

straight lines in this figure show that the activation energy is $\sim 19.4 \mathrm{~kJ} / \mathrm{mol}(0.20 \mathrm{eV} /$ molecule $)$, which is less than that $(46.3-107.1 \mathrm{~kJ} / \mathrm{mol})$ obtained by the standard methods. ${ }^{2}$ The preparation of $\mathrm{SnO}_{2}: F$ film from tin(II) trifuoroacetate also showed the deposition rates of the same order of magnitude as that of $\mathrm{SnO}_{2}$ films.

The $\mathrm{X}$-ray difraction patterns indicated that the crystallinity and the orientation of the films differed depending on kinds of both source material and carrier gas. Figures 2(a)2 (d) show typical examples of the $x$-ray diffaction pattern of the film on a borosilicate glass substrate at a reaction temperature of $350^{\circ} \mathrm{C}$. The $\mathrm{SnO}_{2}: \mathrm{F}$ film prepared from $\mathrm{Sn}\left(\mathrm{CF}_{3} \mathrm{COO}_{2}\right.$ without premixing $\mathrm{O}_{2}$ gas shows textures in the [100] direction [Fig. 2(c)], but peak intensity of the [301] direction increases with increasing reaction temperature or increasing $\mathrm{O}_{2}$ premixing [Fig. $\left.2(\mathrm{~d})\right]$. In the meantime, $\mathrm{SnO}_{2}$ film prepared from $\mathrm{Sn}\left(\mathrm{CH}_{3} \mathrm{COO}\right)_{2}$ without premixing $\mathrm{O}_{2}$ gas showed a nonoriented polycrystalline nature [Fig. 2(a)] and the peak intensities of the (200) and (310) planes increased at $450^{\circ} \mathrm{C}$. Premixing $\mathrm{O}_{2}$ gas into $\mathrm{Sn}\left(\mathrm{CH}_{3}\right.$ $(\mathrm{COO})_{2}$, however, yields a film of very weak crystallinity [Fig. 2(b)]. In short, for preparing $\mathrm{SnO}_{2}$ from $\mathrm{Sn}\left(\mathrm{CH}_{3} \mathrm{COO}_{2}\right.$, premixed $\mathrm{O}_{2}$ prevents crystalline growth, but for preparing $\mathrm{SnO}_{2}: \mathrm{F}$ from $\mathrm{Sn}\left(\mathrm{CF}_{3} \mathrm{COO}\right)_{2}$, premixed $\mathrm{O}_{2}$ gas promotes (301) plane texturing, and $\mathrm{F}$ atoms in $\mathrm{Sn}\left(\mathrm{CF}_{3} \mathrm{COO}\right)_{2}$ promote (200) plane texturing. Thus, oxidation with premixed $\mathrm{O}_{2}$ gas largely affects the crystalline growth, although if gives no effect on the growth rate.

Figure 3 shows the optical transmittances for the 536 mo-thick $\mathrm{SnO}_{2}$ film and the 316-nm-thick $\mathrm{SnO}_{2}: \mathrm{F}$ fim deposited on the borosilicate glass substrate. The transmittances are more than $85 \%\left(\mathrm{SnO}_{2}\right.$ fllm) and $80 \%\left(\mathrm{SnO}_{2}: \mathrm{F}\right.$ film) in the visible range.

Figure 4 shows the electric resistivities of the $\mathrm{SnO}_{2}$ and $\mathrm{SnO}_{2}: \mathrm{F}$ films as a function of reaction temperature, and Fig. 5 shows the resistivity of $\mathrm{SnO}_{2}: F$ film as a function of the ratio of $\mathrm{O}_{2}-t 0-\mathrm{N}_{2}$ gas flow rate. They were obtained with films prepared under the following conditions: source temperature $=140-160^{\circ} \mathrm{C}$, the total fow rate of gas $=0.4$ $\ell / \mathrm{min}$, and the deposition time $=30-60 \mathrm{~min}$. In Fig. 5 , the

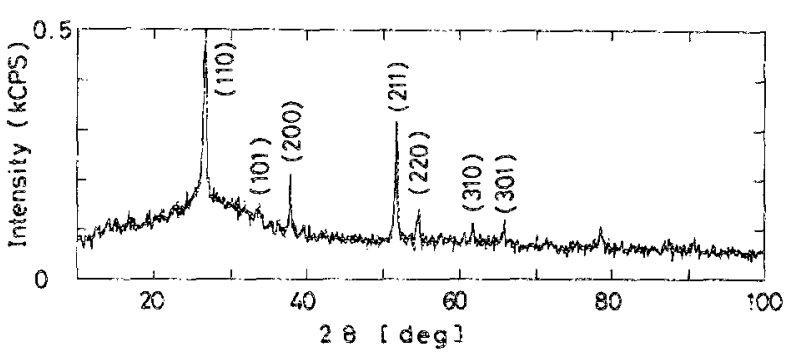

(s)

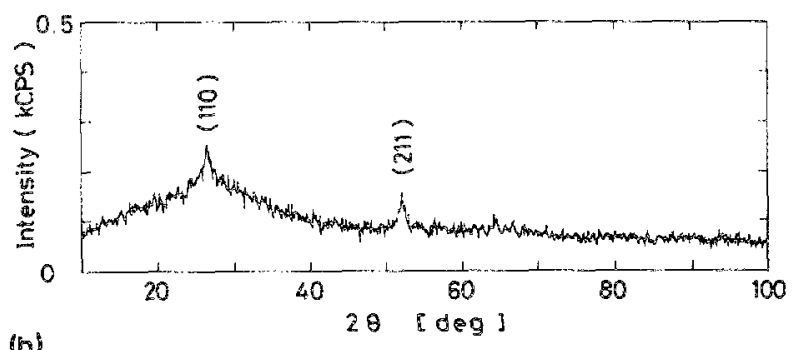

(b)

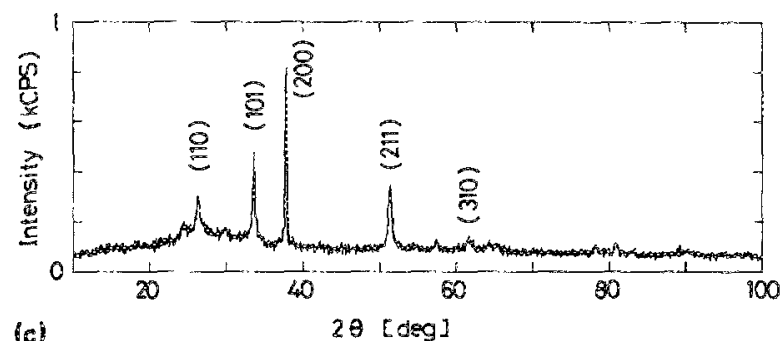

(c)

$2 \theta[\operatorname{deg}]$

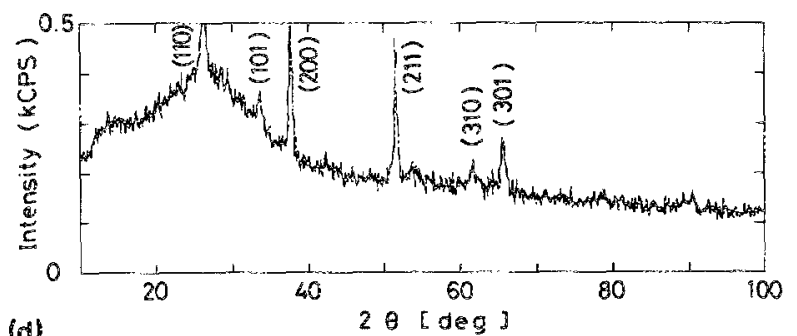

(d)

FIG. 2. X-ray diffraction pattern of fim on borosilicate glass substrate: $\mathrm{SnO}_{2}$ film prepared from $\mathrm{Sn}\left(\mathrm{CH}_{3} \mathrm{COO}\right)_{2}$ (a) without premixing $\mathrm{O}_{2}$ gas and (b) with premixing $\mathrm{O}_{2}$ gas; $\mathrm{SnO}_{2}: \mathrm{F}$ flm prepared from $\mathrm{Sn}\left(\mathrm{CF}_{3} \mathrm{COO}\right)_{2}$ (c) without premixing $\mathrm{O}_{2}$ gas and (d) with premixing $\mathrm{O}_{2}$ gas.

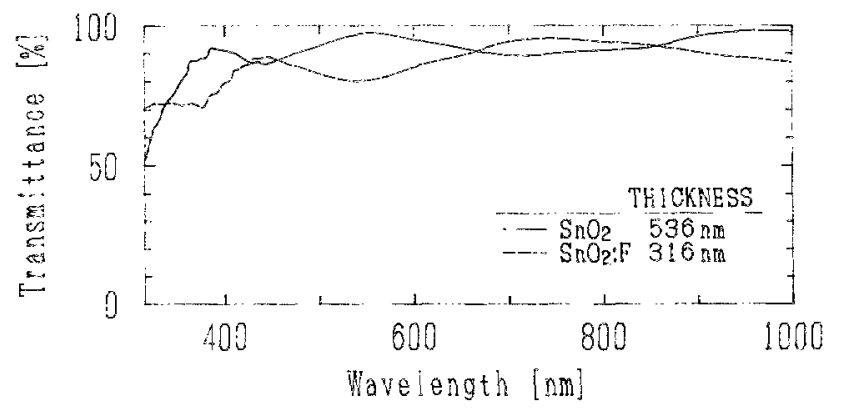

FIG. 3. Optical transmittances of $\mathrm{SnO}_{2}$ film and $\mathrm{SnO}_{2}: \mathrm{F}$ film deposited on borosilicate glass substrate. 


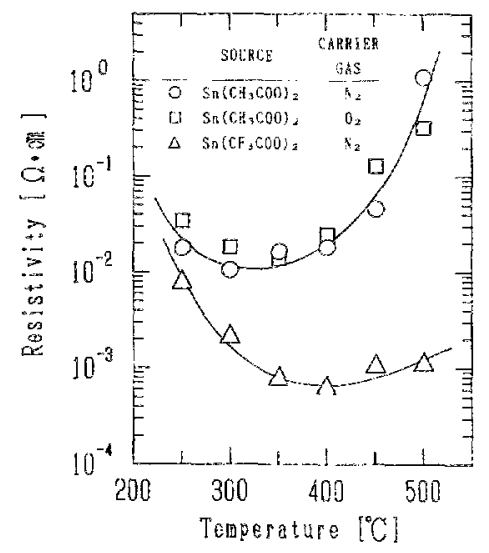

FIG. 4. Electric resistivities as a function of reaction temperature.

resistivity is found to be independent of the ratio $\mathrm{O}_{2} / \mathrm{N}_{2}$ under the wide range of $0 \leqslant \mathrm{O}_{2} / \mathrm{N}_{2} \leqslant 1$. In Fig. 4 the results obtained with premixing $\mathrm{O}_{2}$ gas agree well with the corresponding results without premixing $\mathrm{O}_{2}$ gas. These facts indicate that the electric resistivity is not affected by the changes in crystalline structure caused by the $\mathrm{O}_{2}$ premixing.

In Fig. 4, the resistivity of the $\mathrm{SnO}_{2}: \mathrm{F}$ film is much lower than that of the $\mathrm{SnO}_{2}$ film, and the electric resistivity shows a strong dependence on reaction temperature. The lowest resistivity was obtained for the $\mathrm{SnO}_{2}: \mathrm{F} \mathrm{fl} m$ deposited at $400^{\circ} \mathrm{C}$. After $60 \mathrm{~min}$ of deposition, the film thickness was $1260 \mathrm{~nm}$. The resistivity was $5.92 \times 10^{-4} \mathrm{~S} \mathrm{~cm}$, and the sheet resistance was $4.69 \Omega / \square$.

The structure which gives high electric conductivity will be briefly discussed. Figures $6(a)$ and $6(b)$ show the carrier concentrations and Hall mobilities for both $\mathrm{SnO}_{2}$ and $\mathrm{SnO}_{2}: \mathrm{F}$ films as a function of reaction temperature. It is noted that the carrier concentration for $\mathrm{SnO}_{2}: \mathrm{F}$ film is very high compared to values $\left(\sim 10^{20}\right)$ reported previously ${ }^{1.3}$ for $\mathrm{SnO}_{2}$ iF film. In the meantime, the $\mathrm{F}$ contents of the $\mathrm{SnO}_{2}: \mathrm{F}$ film were obtained by $\mathrm{X}$-ray photoelectron spectroscopy. The values at reaction temperatures 350 and $450^{\circ} \mathrm{C}$ were $0.730 \times 10^{21} \mathrm{~cm}^{-3}(\mathrm{~F} / \mathrm{Sn}=0.0258)$ and $1.178 \times 10^{21} \mathrm{~cm}^{-3}$ $(\mathrm{F} / \mathrm{Sn}=0.0278)$, respectively. Evidently, these values of $\mathrm{F}$ content are close to those of carrier concentration:

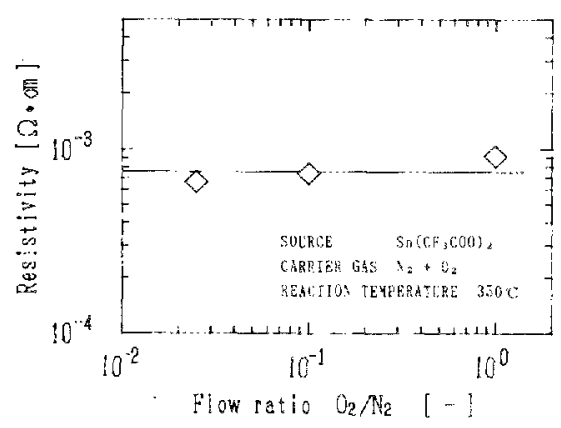

FIG. 5. Electric resistivity of $\mathrm{SnO}_{2}, \mathrm{~F}$ film as a function of flow rate ratio of $\mathrm{O}_{2}$ premixed in $\mathrm{N}_{2}$ carrier.

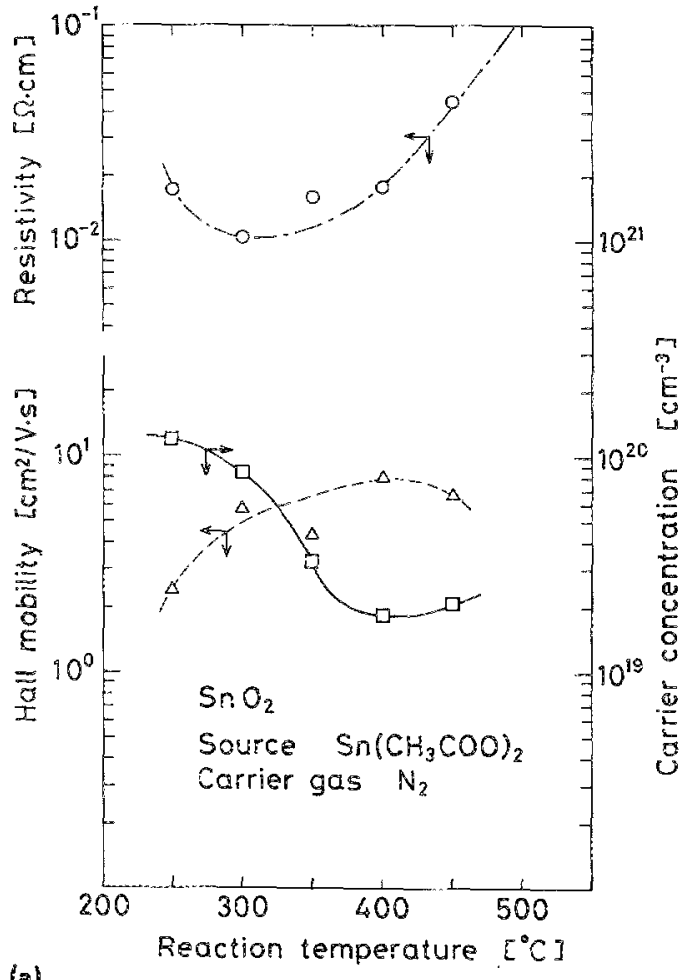

(6)

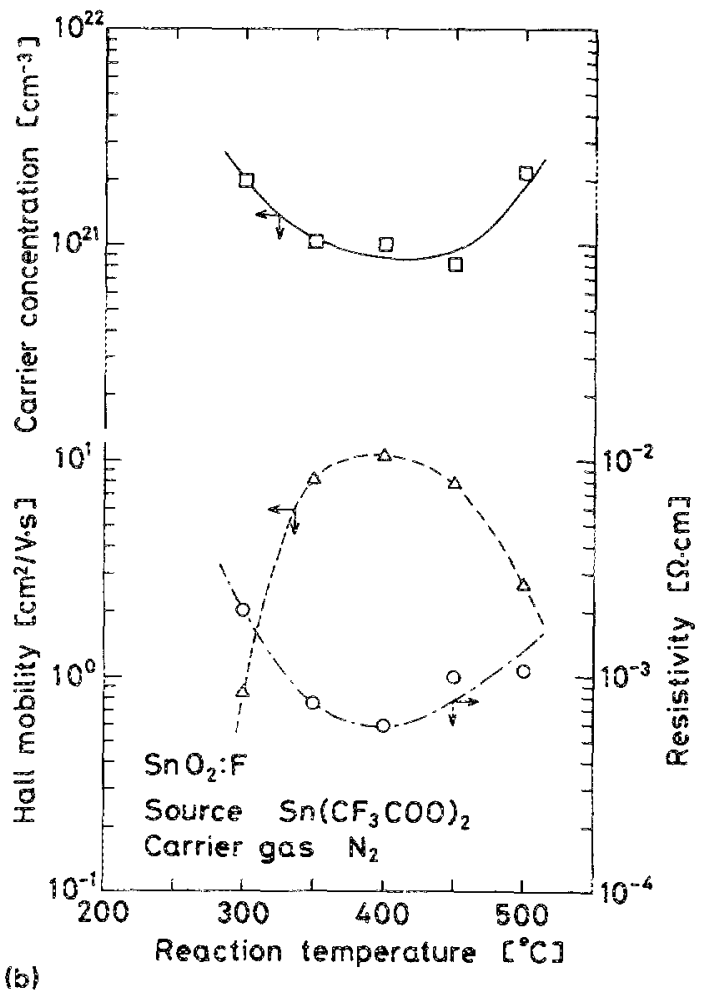

FIG. 6. Electric resistivities, carrier concentration, and Hall mobilities as a function of reaction temperature. (a) $\mathrm{SnO}_{2}$ film, (b) $\mathrm{SnO}_{2}: \mathrm{F} \mathrm{film}$.

$1.024 \times 10^{21} \mathrm{~cm}^{-3}$ at $350^{\circ} \mathrm{C}$ and $0.804 \times 10^{21} \mathrm{~cm}^{-3}$ at $450^{\circ} \mathrm{C}$. Thus, CVD from tin bis-trifluoroacetate effectively incorporates $\mathrm{F}$ atoms into crystalline structure and consequently maximize the carrier concentration. On the other hand, Hall mobilities of $\mathrm{SnO}_{2}: \mathrm{F}$ film are not so high com- 
pared to the reported value $e^{1,3}(\sim 10)$, and they are of the same order of magniude as that of $\mathrm{SnO}_{2}$ film. These smaller values are inferred to be due to undevelopments in crystalline structure of the films which were formed under atmospheric pressure with rather high deposition rate. Thus, the resistivity was insensitive to the differences in crystallinity ( $f \circ \mathrm{SnO}_{2}$ ) and texturing (for $\mathrm{SnO}_{2}: F$ ) of the film in undeveloped state.

\section{CONCLUSIONS}

Transparent conductive tin dioxide thin films were prepared by a low-temperature atmospheric-pressure chemical vapor deposition method in air. The raw material was tin(II) trifuoroacetate. At a reaction temperature above $250^{\circ} \mathrm{C}$, polycrystalline thin films were obtained with a nigh deposition rate. This chemical vapor deposition method effectively incorporates $\mathbf{F}$ atoms into a crystalline structure and consequently maximizes the carrier concentration, yielding fluorine-doped $\mathrm{SnO}_{2}$ films of very low resistivity.
For the $\$ 260$ nm-thick-film deposited at $400^{\circ} \mathrm{C}$, the resistivity was $5.92 \times 10^{-4} \Omega \mathrm{cm}$, and the sheet resistance was $4.69 \Omega / \square$. The reaction temperature and deposition rate were comparable to the corresponding values in the chemical vapor depositions of $\mathrm{SnO}_{2}$ from tin diacetate.

\section{ACKNOWLEGMENTS}

This work was supported by the Japan Securities Scholarship Foundation, Nissan Science Foundation, Iketani Science and Technology Foundation, and Grant-in-Aid for Scientific Research on Priority Area from the Ministry of Education, Science, and Culture, Japan. The authors would like to thank $H$. Kawahara of the Nippon Sheet Glass Co., Ltd. for the Hall coefficient measurements.

'R. Mutoh and S. Furuuchi, Oyo Buturi 41, 41 (1972).

${ }^{2}$ T. P. Chow, M. Ghezzo, and B.J. Baliga, J. Electrochem. Soc. 129, 1040 (1982).

${ }^{3}$ A. K. Saxena, R. Thangaraj, S. P. Singh, and O. P. Agnihotri, Thin Solid Films 131, $121(1985)$. 